\title{
Kendeh-Kirchknopfné Farkis Tímea \\ AZ OLASZ NYELVKÖNYVEK ELEMZÉSE A FORDÍTÁSI FELADATOK TÜKRÉBEN, TÖRTÉNETI KITEKINTÉSSEL:
}

\author{
Fest Aladár olasz nyelvtan. Olvasmányok és társalgások alapján ${ }^{1}$ \\ Honti Rezső: Olasz nyelvkönyv \\ Tóth László: Olasz nyelvkönyv
}

\begin{abstract}
Absztrakt
A tankönyvelemzés nemzetközi szakirodalmában megfogalmazott szempontokon túl célom az, hogy bemutassam azokat az olasz nyelvkönyveket, amelyekben az ötödik idegen nyelvi készségként definiált fordítás még központi szerepet játszik, a tanórák szerves részét képezi, a tanulók anyanyelvi, interkulturális kompetenciájának fejlesztésére is kiemelkedő hatással bír. Elemzésem nem tér ki a különböző nyelvoktatási módszerekre, meghaladná e tanulmány kereteit. A vizsgált tankönyvek (Fest, 1926; Honti, 1940; Tóth, 1966) fordítási feladatai a legegyszerúbb mondatok fordításából kiindulva juttatják el a diákot regényrészlet, novella, sőt vers fordításáig. A klebelsbergi oktatáspolitika alapkoncepciója szerint követik azt a gondolatot, amely szerint az olasz nyelv oktatásával az európai kultúra válik elérhetővé. A fordítási feladatok integrálása az órai munkába, a középiskolai nyelvoktatás rendszerébe több szempontból is ajánlatos lenne napjainkban. A fordítási feladatok a modern nyelvoktatás és pedagógia alapkompetenciáival is összhangban állnak. Fejlesztik az anyanyelvi kompetenciát, a logikus gondolkodást, segíti az interkulturális kommunikációt.
\end{abstract}

Kulcsszavak: olasz nyelv; fordítás; tankönyv

\section{A tankönyvkutatásról}

Kutatásaim célpontjában a Magyarországon, különböző történelmi időszakokban megjelent olasz nyelvkönyveket elemzek, különös tekintettel a fordítási feladatokra. A tankönyvelemzés nemzetközi szakirodalmában megfogalmazott szempontokon túl (F. Dárdai, 1999), (F. Dárdai \& Kojanitz, 2007) célom az, hogy bemutassam azokat az olasz nyelvkönyveket, amelyekben az ötödik idegen nyelvi készségként definiált (Bárdos, 2000) fordítás még központi szerepet játszik, a tanórák szerves részét képezi, a tanulók anyanyelvi, interkulturális kompetenciájának fejlesztésére is kiemelkedő hatással bír.

A különböző történelmi időszakokban megjelent olasz nyelvkönyvek hűen tükrözik a korszak szellemiségét, politikai nézeteit. Ebben az elemzésben Fest Aladár Olasz nyelvtan. Olvasmányok és társalgások alapján című tankönyvét vizsgálom, amelyet 1926-ban engedélyezett a magyar királyi vallás- és közoktatásügyi miniszter. Honti Rezső Olasz

1 A magyar királyi vallás- és közoktatásügyi Miniszter úr ezt a könyvet jelen kiadásában 27.841/1926. számú rendeletével középiskolák számára tankönyvül engedélyezte 
nyelvkönyve 1940-ben jelent meg. Az 1966-ban megjelent Olasz nyelvkönyv pedig Tóth László, egyetemi magántanár, a nápolyi Istituto Universitario Orientale megbízott előadójának tankönyve. Nem térek ki a különböző nyelvoktatási módszerek bemutatására, mivel az általam vizsgált olasz tankönyvek módszertani elemzése túllépné a megadott kereteket.

A tudományos alapokon álló tankönyvkutatás alapjait 1986-ban a Bielefeldi Egyetem három professzora dolgozta ki, akik totalitásra törekvő vizsgálati rasztert alkottak, amelyben öt dimenzió mentén 24 vizsgálati kategóriát helyeztek el. „Ezt nevezték el a későbbiekben »bielefeldi raszternek«, amelyet a pedagógiai szakemberek elismerésre méltó tudományos dokumentumként tartanak számon, de amelyet a gyakorlatban nem igazán tudtak hasznosítani." (Kaposi, 2012, p.59)

A Thonhauser által kidolgozott «funkcionális» modell, három tényezőre építve határozza meg a tankönyvet. (Kaposi, 2012, p. 60)

„Az értelmezés szerint a tankönyv (1) iskolai oktatási és tanulási folyamatot alátámasztó médium, (2) államilag engedélyezett és támogatott eszköz és kortörténeti dokumentum, valamint (3) tudatos kalkuláció által létrehozott gazdasági tényező. E megközelítéshez képest Weinbrenner a tankönyv fogalmát, tágabban értelmezi - ezért is nevezhetjük „komplex” modellnek. Folyamatot, terméket vagyis produktumot, és szocializációs faktort ért alatta, és ennek értelmében különít el háromféle kutatási aspektust, területet. A folyamatorientált tankönyvkutatás, a tankönyv keletkezésével azon belül szerzők, kiadók; engedélyezési eljárások; tankönyv és piac összefüggéseivel; a tankönyv kipróbálásával; használatával; selejtezésével és megsemmisítésével foglalkozik. A produktumorientált tankönyvkutatás, a tankönyvet, mint az oktatás és vizuális kommunikáció eszközét vizsgálja. Ide tartoznak a tartalomelemző eljárások. A megközelítés külön dimenzióként különíti el ezen belül a tudományelméleti, szaktudományi, szakdidaktikai, neveléstudományi dimenziót és designt (külső forma, szín, grafika, tipográfia). A hatásorientált tankönyvkutatás a tankönyvet az oktatás szocializációs tényezőjeként tekinti, a kutatás pedig recepciókutatás. Arra kíváncsi, hogy milyen hatást gyakorol a tankönyv a diákokra, tanárokra, a közvéleményre; milyen világképet, érték- és gondolkodási mintákat, előítéleteket, ellenségképet közvetít." (F. Dárdai, 2002, pp. 55-60)

A Magyarországon megjelent tankönyv-kutatással foglalkozó elemzések szoros kapcsolatban állnak a téma nemzetközi tendenciáival. F. Dárdai Ágnes által javasolt elemzési szempontok tehát a következők:

- A szerző didaktikai felfogását tegye világossá a bevezetőben.

- A tanulók életkori, pszichikus sajátosságainak, értelmi és lelki fejlettségi szintjének való tankönyvi megfelelés (olvashatóság, mondatok, szavak hosszúsága, megfelelő kifejtettség és redundancia, gondolkodásra késztetés) jelenjen meg.

- Legyen életszerű, életközeli a tankönyv; mind tartalmában, mind a külső megformálásban a tanulók érdekeit tartsa szem előtt.

- Törekedjen az „egyetlen igazság” hirdetésének kerülésére, alkalmazzon multiperspektivikus megközelítést és a tartalomban, valamint a módszerekben, sokféleség jellemezze. 
- A kérdések haladják meg a puszta reprodukció szintjét, és ösztönözzenek a gondolkodás magasabb műveleteire is (elemzés, összehasonlítás, értékelés).

- A módszertani megoldások egymással legyenek összhangban és arányban (ismeretközlés, képességfejlesztés, értékközvetítés).

- A szöveg és illusztráció aránya (kép, grafikon, ábra, térkép) legyen 30-50 százalék között.

- Tudományosan feleljen meg a szakmai igényességnek.

- Előítélet-mentesség jellemezze, a sztereotípiák kezelésére is tegyen kísérletet.

- Európaiság jellemezze látásmódját.

- Környezetbarát szemléletre ösztönözzön.

- Jellemezze transzparencia: mindenki számára legyen világos a felépítése, aki kézbe veszi." (F. Dárdai, 2002, p. 63; Kaposi, 2012, p. 66)

A tankönyvkutatás dimenziói és a tankönyvkutatás szempontjai a jelenlegi álláspont szerint a következők:

Ha tankönyvet, mint kordokumentumot tekintjük, természetesen történeti megközelítést alkalmazunk. Ha a tankönyvet, mint informatoriumként értékeljük, akkor elkerülhetetlen a szaktudományi/tantárgypedagógiai elemzés. A tankönyv, mint politikum, egyidejüleg hordoz politikai-ideológiai üzeneteket. A tankönyv, mint pedagogikum, természeténél fogva pedagógiai/didaktikai álláspontokat tükröz.

A tankönyv, mint médium kommunikáció-elméleti, nyelvészeti, recepcióelméleti megközelítést is igényel. Mindazonáltal nem lehet eltekinteni attól, hogy a tankönyv, mint szocializációs faktor szociológiai, pszichológiai szempontok alapján is értékelhető. Végül, a tankönyv, mint termék, ökonómiai, gazdaságtani, esztétikai megjelenése a kor képét is magán hordozza. (F. Dárdai, 1996, p. 52)

\section{A tankönyv, mint kordokumentum}

Tehát az előzőekben felvázolt tankönyvkutatási javaslatok mentén haladva igyekeztem az általam vizsgált olasz tankönyveket bemutatni. Kordokumentumnak kell tekinteni mindegyiket, és éppen ezért tartom szükségesnek, hogy a megjelenésük időszakát is röviden ismertessem. A történeti kitekintésre azért van szükség, mivel azok az olasz nyelvkönyvek, amelyekben a fordítási feladatok jelentőségét vizsgálom, olyan kiemelkedő oktató-kutató munkát végző személyek tollából születtek, akik a korszak meghatározó tudósai, fordítói is voltak. Fest Aladár, 1923-tól olasz nyelvet tanított a Budapesti Egyetem Gazdaságtudományi Karán, és komoly fordítói múlttal büszkélkedhetett. (Pelles, 2000). Honti Rezső fordításai közül kiemelendő az 1922-ben megjelent Machiavelli Mandragórája és Machiavelli Belfagor című művének magyar fordítása 1927-ben. (Kaposi, 2012, p. 22) Honti Rezső szótárszerkesztő és műfordító tudós olasz nyelvkönyve még 1954-ben is használatban volt. Az 1966-ban kiadott olasz nyelvkönyv szerzője, Tóth László egyetemi oktató, aki 1934-ben a pécsi egyetem olasz tanársegédjeként szerzett tanári diplomát. 1935-ben a magyar nyelv lektora a római egyetemen, és egyúttal a Római Magyar Akadémia titkára. 
Az olasz nyelv tanításának bevezetése Klebelsberg Kunó nevéhez fűződik. Az általa képviselt oktatáspolitikai reformnak köszönhető az, hogy Magyarországon megjelent a közoktatásban az olasz nyelv és irodalom oktatása. Gróf Klebelsberg Kunó 1927. évi római látogatása alkalmával így méltatta középiskolai reformját:

„Javaslatomra a nemzetgyűlés törvényt alkotott a fiú- és leányközépiskolákról. Mindkét törvénynek lényeges rendelkezése az olasz nyelvnek és irodalomnál kötelező tantárgyként való bevezetése a magyar középiskola tantervébe. Pedagógusnak nem kell bővebben magyaráznom, hogy a középiskola az egész tanügynek éppen az a része, amely a gyakori módosításokat a legkevésbbé (sic) bírja meg és éppen azért igen fontos okoknak kellett lenni azoknak, melyek e lépésre késztettek." (Klebelsberg, 1927, pp.238-239)

E tanulmánynak nem célja részletesen ismertetni azokat a politikai, gazdasági, társadalmi okokat, amelyek az iskolareformhoz vezettek (Szabó, 2000), s nem áll szándékomban annak fogadtatásával, kritikájával foglalkozni. Mindazonáltal magát a törvényt, annak rövid bemutatását elengedhetetlennek tartom, hiszen az olasz nyelv bevezetésével létrejött egy új iskola, egy új pedagógiai koncepció is, amelyben az olasz nyelv oktatása kiemelt jelentőséggel bírt. „A középiskolának az a feladata, hogy a tanulót vallásos alapon erkölcsös polgárrá nevelje, hazafias szellemben magasabb általános műveltséghez juttassa és a felsőbb tanulmányokhoz szükséges szellemi munkára képessé tegye. A közös nemzeti tárgyakon kívül a gimnázium e feladatot a minden irányú humanisztikus, elsősorban latin- és görögnyelvi és irodalmi tanulmányokkal, a reálgimnázium főleg a latin- és modernnyelvi és irodalmi tanulmányok segítségével, a reáliskola különösen a modern nyelvek és irodalmak, úgyszintén a mennyiségtani és természettudományi tárgyak tüzetesebb tanításával oldja meg.” (Magyar joganyagok 1924. évi XI. törvénycikk a középiskoláról, Netjogtár. https://net.jogtar.hu)

\section{Az 1924. évi XI. törvénycikk és az olasz nyelv oktatásának helyzete Magyarországon}

Az 1924. évi törvénycikk a középiskoláról rendelkezett tehát arról, hogy a reálgimnáziumok és a reáliskolák rendes tantárgyai közé bekerüljenek a következő tantárgyak: angol vagy francia vagy olasz nyelv és irodalom. Szeretném már itt kihangsúlyozni, hogy nem egyszerűen a nyelv oktatása került fókuszba, hanem a nyelvhez tartozó kultúra és irodalom is. A törvény a továbbiakban a következő megállapítást teszi: „6. § Élő idegen nyelvek megválasztása. A 3. § e) és a 4. § d) pontjaiban felsorolt élő idegen nyelveknek egyike lehet a tanítás rendes tárgya egy-egy reálgimnáziumban, illetőleg reáliskolában. Hogy közülök melyik taníttassék, azt az állami és királyi katholikus, valamint a törvényhatósági, községi, társulati és magán középiskolákra nézve a m. kir. vallás- és közoktatásügyi miniszter, a többi intézetekre nézve pedig az illetékes hatóság állapítja meg." (Magyar joganyagok - 1924. évi XI. törvénycikk a középiskoláról, Netjogtár. https://net.jogtar.hu)

Klebelsberg Kunó 1927-ben, Rómában erre a törvényre hivatkozva tartotta meg beszédét. Felvázolta a két ország közötti évszázados kulturális, politikai, gazdasági kapcsolatok jelentősebb állomásait. Itt azokat a gondolatait emelem ki, amelyek az olasz 
nyelv oktatásának jelentőségét hivatottak bemutatni. Röviden szeretném összevetni azokkal a gondolatokkal, amelyek a 2006. december 18-án elfogadott Európai Parlament és Tanács megfogalmazása szerint tudásalapú társadalomban minden egyén számára alapvető fontosságú kompetenciák.

Az Európai Parlament és Tanács megfogalmazása szerint a nyolc kulcskompetencia a következő:

1. Anyanyelven folytatott kommunikáció: annak képessége, hogy az egyén fogalmakat, gondolatokat, érzéseket, tényeket és véleményeket tud kifejezni és értelmezni szóban és írásban egyaránt.

„Nem szabad beérnünk azzal sem, hogy az olvasmányok révén futó bepillantást engedjünk az illető nemzet irodalmába. Arra a magasabb célra kell törekednünk, hogy a tanuló kerek képet kapjon egy nép kultúrájának lényegéről." (Klebelsberg, 1927, p.239)

2. Idegen nyelven folytatott kommunikáció: a fentieket mediációs készségekkel egészíti ki (pl. összefoglalás, parafrazeálás, tolmácsolás vagy fordítás), valamint interkulturális megértés.

„Figyelembe vettem, hogy az olasz nyelv rendszere, az olasz nyelvtan logikailag legalább is annyira kicsiszolt, mint a francia vagy a német és ilyen körülmények között arra a logikai iskolázásra, melyet egy tökéletesen kifejlesztett grammatika a tanuló elméjének nyújt, teljesen megfelel. (Klebelsberg, 1927, p. 239)

3. Matematikai, tudományos és műszaki kompetenciák: magabiztos számolni tudás, a természeti világ működésének megértése, valamint a tudás és a technológia alkalmazása az érzékelt emberi szükségletekre adott válaszként (pl. orvostudomány, közlekedés vagy kommunikáció).

„Ma a kultúrkép teljessége okából igyekszünk kiterjeszkedni a képző- és a zeneművészetre is, sőt meg akarjuk mutatni, hogy mit tett az illető nemzet a találmányok, a felfedezések s a tudományok terén. Ha ebből a szélesebb kultúrpolitikai szemszögből nézem az olasz művelődést, meg kell állapítanom, hogy az olasz kultúra voltaképpen az újkor alapművelődése, melynek beható ismerete nélkül az újkor civilizációját meg sem lehet érteni." (Klebelsberg, 1927, p. 239)

Természetesen Klebelsberg a 4. Digitális kompetenciáról nem értekezhetett, ahogy a saját tanulás egyéni vagy csoportos megszervezésének képessége is a kor körülményeit figyelembe véve egész más módon zajlott. (5. kompetencia: A tanulás elsajátítása.) Ám a 6. Szociális és állampolgári kompetenciák (hatékony és építő módon történő részvétel a társadalmi és szakmai életben, valamint aktív és demokratikus állampolgári részvétel, különösen az egyre sokfélébb társadalmakban.) és a 7. Kezdeményezőkészség és vállalkozói kompetencia (az elképzelések megvalósításának képessége a kreativitás, innováció és a kockázatvállalás révén, valamint a tervek készítésének és végrehajtásának képessége.) ismét párhuzamba állítható a klebelsbergi oktatáspolitika elképzeléseivel, az olasz nyelv és kultúra tanításával, tanulásával. „A humanizmus és ikertestvére, a renaissance; a barokk, mely azt tovább fejlesztette és a klasszicizmus, mely felváltotta, éppúgy olasz kreáció, mint az újkor szerelmi lírája és eposza, vagy az opera és a szimfónia vagy a gimnázium és a dalszínház vagy a zenei és képzőművészeti iskola." (Klebelsberg, 1927, p. 239) 
Az utolsó kompetencia, 8. Kulturális tudatosság és kifejezőkészség (az elképzelések, élmények és érzések kreatív kifejezése fontosságának elismerését a különböző művészeti ágakban, a zenében, az irodalomban, a képzőművészetben és az előadó-művészetben). „A meggyőződés az, hogy az olasz nyelv és művelődés beható oktatása nélkül a magyar középiskola az újkori művelődés fejlődésének igazi képét nem adhatná." (Klebelsberg, 1927, p. 240)

Látható, hogy az 1927-ben Rómában elhangzott, ma is modernnek tekinthető beszédében Klebelsberg Kunó megfogalmazta azokat a kardinális pontokat, amelyek a 2006. december 18-án elfogadott Európai Parlament és Tanács megfogalmazásában is helyet kaptak mint kulcskompetenciák (kivéve, értelemszerűen a digitális kompetenciára vonatkozó alapvetéseket). Az olasz nyelv és irodalom oktatásának Magyarországon való bevezetéséhez tehát e koncepció vezetett. Ennek az oktatáspolitikai meggyőződésnek a gyakorlatban való megvalósításához tanárok és tankönyvek kellettek. A törvény e problémának megoldásával is foglalkozott:

„Valahányszor új tantárgy oktatását vezetjük be a középiskolába, annak megvan a maga következése a tanárképzés terén is. Gondoskodnunk kell tehát arról, hogy kellő számmal rendelkezzünk olyan középiskolai tanárokkal és tanárnőkkel, akik az olasz nyelvet tökéletesen bírják és az olasz irodalomban, művészetben, képzőművészetben és zenében egyaránt járatosak. A kezdet nehézségein átsegített bennünket az olasz kir. kormány, amely Durini gróf budapesti követ úr közbenjárására átmenetileg olasz középiskolai tanárokat bocsátott rendelkezésemre. Több fiumei olasz eredetű középiskolai tanárunk is van, akik az olasz nyelv tanítására képesek. A budapesti és pécsi egyetemeken azonfelül katedrát létesítettünk az olasz irodalomnak és nagy örömmel látom, hogy az olasz szakot választó modern filológusok száma bölcsészethallgatóink között állandóan nő. Ezeket azonban csak két éven át kívánom Magyarországon iskoláztatni s azután ösztöndíjjal a római egyetemre küldöm őket. Ez az akció már megindult és az ösztöndíjak számának szaporításával a jövőben még lényegesen ki akarom építem. Ekként rendszeresen biztosítva van az, hogy az olasz nyelv oktatása ne maradjon a magyar tantervek papírján írott malaszt, hanem az Olaszországban képzett középiskolai tanárok révén menjen át az életbe." (Klebelsberg, 1927, pp. 249-250)

\section{Olasz nyelvkönyvek Magyarországon (Fest:1926; Honti:1940; Tóth:1966)}

A tankönyvek kiválasztása nem véletlenszerű, hanem tudatos döntés volt. Mint kortörténeti dokumentumok, hűen tükrözik a magyarországi oktatáspolitika eszméit, ugyanakkor rendkívül modern szemlélettel rendelkeznek. Ma, 2020-ban rendelkezésünkre áll a nyelvtanítás sikerességéhez minden olyan eszköz - internet, különböző applikációk, hanganyagok, hangoskönyvek stb. -amelyekkel a nyelvtanár élvezetesebbé, sikeresebbé tudja tenni óráját. Interaktív órákkal tudja ébren tartani a tanuló motivációját, figyelmét. Az erre vonatkozó ajánlásokat fogalmazta meg az Európai Parlament és Tanács a kompetenciák összegzésében. A nyelvoktatás sikerességének vizsgálata számos tanulmány témája, ám a szakértők szerint is elengedhetetlen 
visszatérni az elmúlt korszakok forrásaihoz. „Ahhoz, hogy új szemléletet vagy új módszert tudjuk kínálni valamire, tisztában kell lennünk a fejlődés eddigi ívével, hiszen az előzmények ismeretében mondhatjuk, hogy mi az, ami még ma is érvényes és mi az, ami fölött eljárt az idő; mi az, ami múködik és mi az, amit meghaladtunk; milyen kihívások voltak régen és milyen kihívásokkal találkozunk ma." (Bakti et al, 2018, p. 5)

A hallott szöveg értése és a beszédkészség fejlesztése a tanórán az egyik legfontosabb alaptevékenység, amelynek során fejlődik a diák interakciós készsége, a célnyelvi kommunikáció. Az olvasott szöveg értése, azaz a szövegértés egy rendkívül összetett folyamat. A legegyszerűbb mondat értelmezése a nyelvtanulás elején éppen olyan nehéz, mint egy összetett, szaknyelvi szöveg értelmezése a haladó nyelvtanulónál. Az íráskészség fejlesztése során elengedhetetlen figyelembe venni a tanulók életkori sajátosságait, érdeklődési körét, anyanyelvi kompetenciájuk fejlettségi szintjét. E kompetenciák fejlesztése áll tehát jelenleg is a nyelvtanulás, nyelvtanítás fókuszában. Az interkulturális kommunikáció témái természetesen koronként változnak. A globalizáció miatt ennek üteme rendkívüli módon felgyorsult, amelyhez való alkalmazkodás a nyelvet oktató tanár egyik legnagyobb kihívása jelenleg. Mindazonáltal, az elődeinkhez való visszafordulás nagyon sok hasznos tapasztalattal gazdagíthatja a gyakorló pedagógusokat.

Antal Lajos a kiváló italianista XVII-XVIII. századi olasz nyelvkönyvek elemzésekor arra buzdítja a kutatókat, hogy olvassunk bele a könyvekbe, hiszen „a korabeli nyelvtanítási módszerekről bőséges leírást találunk a nyelvkönyvek bevezetéseiben, ajánlásaiban, az előszókban tehát, amelyeket mindeddig a szakirodalom kevés figyelemre méltatott, azzal az indokkal, hogy a tanítás gyakorlata valószínűleg jelentősen különbözött a szerzői elképzelésektől. Meglehet; viszont nem hagyhatjuk megjegyzés nélkül azt a tényt sem, hogy maguk a szerzők is nyelvtanárok." (Antal, 1979, p. 166)

Fest Aladár olasz nyelvtan és irodalom könyvét a kor szellemének, törvényi kötelezettségeit betartva írta (Stelli, 2014). Személye, az olasz-magyar kulturális kapcsolatok terén kifejtett tevékenysége, pedagógiai pályafutása, tudományos karrierje több esszé, kutatás tárgya volt Olaszországban és Magyarországon egyaránt. (Józsa \&Peles, 2000, pp.148-153) 1855-ben született Egerben, Budapesten földrajzból és történelemből diplomázott. Magántanárként tanított egy évig Almásy Kálmán birtokán Kétegyházán. „1880-ban a félegyházi katolikus algimnáziumhoz nevezték ki tanárnak, ahonnan félévi szolgálat után a VKM olaszországi tanulmányútra küldte. Másfél évi ott tartózkodása alatt tanult a római és a pisai egyetemen, de hosszabb időt töltött Firenzében és Riminiben is. Visszatérte után, 1882 szeptemberétől helyettesítési évek nélkül kinevezték a fiumei főgimnázium történelemtanárává. 1894-ben - saját kérésére áthelyezték a budapesti II. kerületi katolikus főgimnáziumhoz. Két évvel később, Berghoffer József halála után, igazgatóként térhetett vissza a fiumei főgimnáziumhoz, amelyet tizenöt éven át vezetett. (...)1923-tól Fest a budapesti egyetem közgazdaságtudományi karán olaszt tanított néhány évig. A közéletben aktív szerepet vállalt, számos egyesületnek volt tagja, többnek vezetőségi tagja is. Bekapcsolódott a Budapesten virágkorát élő magyar-olasz kulturális életbe. Közben számos publikációja jelent meg magyar és olasz nyelven. Élete utolsó éveit visszavonulva töltötte. Magas 
életkort élt meg, 1943-ban, 88 éves korában ragadta el a halál." (Józsa\&Peles, 2000, pp. 148-153)

Fest Aladár tudományos és pedagógia pályafutásának rövid összegzéséből egy olyan tudós-tanár alakja bontakozik ki, aki egyértelműen elkötelezett hivatástudattal vallotta és alkalmazta azokat az alapkompetenciákat, amelyeket az előző oldalakon felvázoltam. Nagy jelentőségű, pedagógiai tárgyú olasz nyelven publikált művein túl (Fest, 1887, 1889) 1926-ban a Királyi Magyar Egyetemi Nyomda kiadásában megjelent az olasz nyelvet tanulók számára írt könyv: La grammatica italiana in base a letture e conversazioni.

A nemzetközi és hazai szakirodalomban javasolt tankönyvelemzési módszereket figyelembe véve, megállapítható, hogy Fest Aladár tankönyve az iskolai oktatási és tanulási folyamatot alátámasztó médium, államilag engedélyezett és támogatott eszköz és kortörténeti dokumentum. Fest Aladár ebben a tankönyvben nem írt bevezetőt, így közvetlenül nem tudjuk meg milyen didaktikai felfogás vezérelte, ám a kor pedagógiai szellemiségéhez, s azon belül is a már említett klebelsbergi beszéd koncepciójához is igazodott (Vallás-és Közoktatásügyi Minisztérium engedélye:36.298/1926).

Megállapíthatjuk, hogy a tanulók életkori, pszichikus sajátosságainak, értelmi és lelki fejlettségi szintjéhez alkalmazkodik, hiszen könnyedén olvasható, a mondatok, szavak hosszúsága, megfelel egy, az olasz nyelvet kezdő diák felkészültségének.

Életszerű, élet közeli a tankönyv, tartalomjegyzéke igazodik a diákok érdeklődési köréhez. E témakörök a jelenlegi nyelvkönyvekben is ebben a sorrendben találhatók. Felépítésében minimális eltérés tapasztalható. Az olasz nyelv és a latin nyelv rokonsága, nyelvtani rendszerének hasonlósága miatt nehezen feleltethető meg a multiperspektivikus megközelítésnek, nem jellemzi módszerek sokfélesége. Grammatizáló, kontrasztív nyelvészeti felépítésű.

A leckék, témakörök után található kérdések nem haladják meg a puszta reprodukció szintjét. Ennek oka a grammatizáló módszer (latin, olasz rokonság), ám a tankönyv végére eljuttatják a diákot magasabb szintre, önálló mikrofordítások elvégzésére teszik alkalmassá a nyelvtanulót. „Ez a módszer a nyelvet mechanizmusnak tekinti, s azt tartja, hogy annak részeit tetszés szerint szedhetjük szét és rakhatjuk újra össze. Csak meg kell találnunk az összekapcsolást meghatározó törvényeket és c műveletet magunk is elvégezhetjük. A nyelvet olvasva kell megtanulni, a nyelvtanulás tehát receptiv. Később már nemcsak receptív, hanem reproduktív nyelvtudásra törekszenek. Majd a tanítás anyaga mindinkább közelebb jut az élethez, a nyelvtan elveszti fontosságát, de az anyanyelvről az idegen nyelvre való fordítás még mindig az érdeklődés előterében marad." (Rakonczai, 1942, p.6) Tudományosan tehát megfelel a kor szakmai igényességének.

A tankönyvben nem valósul meg az elvárt arány a szöveg és az illusztráció között, a kor technikai fejlettsége ezt nyilvánvalóan nem tette lehetővé.

A kor politikai, diplomáciai szelleméhez igazodva, az olasz-magyar kapcsolatok erősítésére helyezi a hangsúlyt, a sztereotípiák kezelésére is kísérletet tesz, de a két háború közti időszakra jellemző módon. A tankönyv európaisága kimerül a két ország közti történeti folytonosság bemutatásában. 
Témakörök, olvasmányok: Család, bemutatkozás, Budapest, vidék-városi élet. Párbeszédek, amelyek a kommunikációs készséget fejlesztik. Az utazás témakörnél egyértelművé válik, az, hogy ez a tankönyv kordokumentum (Trianoni békekötés). A 41. lecke témája egy kirándulás, amelynek során a két diák Versaillesbe látogat el, és megtekintik a Trianon palotát, ahol a „gyászos” (funeste) békekötésre emlékeznek. A tankönyv politikum, politikai-ideológiai témaválasztásában, a tankönyv pedagogikum, hiszen az emlékezet, emlékeztetés a célja.

Fest Aladár nem írt bevezetést nyelvkönyvéhez, ám Rakonczay János 1942-ben írt ajánlásában, amelyeket a modern nyelvek tanításához szánt, a következő módszertani megjegyzéseket tudhatjuk meg: „Az olvasmányok anyaga alsó fokon az iskola, a család, a ház, a lakás, az étkezés, a város és a falu, kert és az udvar, a napi teendők, az időmérés, az időjárás, kirándulás stb. Formája szerint az olvasmány lehet egyszerű leírás vagy párbeszéd. A leírás mindig elevenebb, ha esemény keretébe van foglalva, még élénkebb a párbeszédes forma. Az olvasmányoknak tartalmazniok kell egész évre elosztva a mindennapi életnek 800-1000 szavát. Ha tekintetbe veszszük (sic!), hogy heti négy órát véve alapul harminc munkahét alatt kb. 120 órára számíthatunk, amelyből dolgozatokra esik 16 óra, 20 órát pedig az ismétlésekre szánunk, az évi anyag elvégzésére $85-80$ órára számíthatunk. Ez pedig annyit jelent, hogy egyegy órára 10-14 új szó esik. Az olvasmánynak, hogy lekösse a tanuló figyelmét érdekesnek kell lennie és főleg meg kell felelnie lelki fejlődése egyes fokainak." (Rakonczai, 1942, p.9)

Fest Aladár könyvében a nyelvtani egységek tárgyalása, gyakoroltatása szinte teljesen megegyezik a mai nyelvkönyvekével. Abban tapasztalható minimális eltérés, hogy a különböző múlt idők tárgyalását egymás után leckékben ismerteti (imperfetto, passato prossimo, trapassato prossimo). Ennek oka nyilvánvalóan az, hogy a diákok a latin nyelv tanulása mellett kezdték el az olasz nyelvet tanulni, és számukra nem jelentett különösképpen nagy nehézséget ezen nyelvtani igeidők elsajátítása, megértése.

„A modern nyelvek tanításában volt egy hosszú korszak, amikor a klasszikus nyelvek példájára a nyelvtan állott a tanítás középpontjában. A tanulóknak meg kellett tanulniok bizonyos szabályokat s ezek segítségével újra fel kellett építeniük a nyelvet. Ez volt a grammatizáló módszer ideje.(...) E gépiesen utánzó módszer nem méltó a nevelő iskolához. Igy alakult ki a mai közvetítő módszer. A nyelvtan ebben nem cél, hanem eszköz. Éppen ezért nagyon meg kell válogatni a nyelvtan anyagát. Csak azt taníthatjuk, ami élő, ami nem elavult. Követendő módszerünk induktív. Példákból indulunk ki, hogy eljussunk a törvényhez. Az induktív módszer megkívánja, hogy alsóbb fokon az olvasmányok bizonyos sorrendben legyenek összeállítva." (Rakonczai, 1942, pp.12-13)

Fest Aladár nyelvkönyve tökéletesen követi az előírásokat, miszerint a kezdő lépésektől az igeidőegyeztetés összetett problematikájáig kíséri az olaszul tanuló diákot. Minden témakör után, repetitív feladatok találhatóak (gyakorló feladatok), amelyek nyelve olasz és magyar. A nyelvtani szabályok megfogalmazása szintén magyar nyelven történik. Az interkulturális kommunikáció rendkívül hangsúlyos szerepet kap a tankönyvben. Már 9. leckénél (Fest, 1926, p.43) a tanuló Ada Negri, Nevicata (Havazás) című versén keresztül ismeri meg az időjárás alapszókincsét. Nagyon fontos a 39. lecke, amely Giosuè Carducci, Al Re (A Királyhoz) című versére épül kizárólag, amelynek 
értelmezése során Olaszország egységesítésének folyamatát is megismerhette a tanuló. E vers értelmezése mindenképpen felkészült nyelvtanárt igényelt, olyan humán értelmiségi oktatót, akik jártas Itália történelmében, irodalmában.

Fordítási feladatok minden egység után, a diák pillanatnyi felkészültségéhez igazodva készültek (Dite in italiano!). Nagyon fontos az a tény, hogy a fordítási feladatok csak a 3. lecke után szerepelnek, hiszen a bevezető stúdiumok (kiejtés, alapvető nyelvtani szabályok ismertetése) után lehetett elkezdeni, lépésről lépésre. Az 5. leckéig csak olaszra fordítandó mondatok szerepelnek a feladatok között. Az 5. lecke a család, az otthon témakör tárgyalására szánt fejezet, amelynek végén megjelennek a nyelvtani gyakorló feladatok után azok a fordítási feladatok, amelyek olaszról magyarra fordíttatják a diákokat. Fest Aladár 49. leckére tervezte könyvét, de már az 5. leckétől mindkét nyelvről fordíttatja a diákokat.

A tankönyvben minden igeragozás mellett megtaláljuk a magyar megfelelőjét. Minden egység után szószedet (vocabolario), és italianizmusok gyűjteménye támogatja a tanulót. A 40. lecke már Franciaországba, Trianonba viszi a tanulókat. A kor szellemiségének megfelelően a nemzeti emlékezést, a trianoni traumára való emlékezést erősíti.

Honti Rezső Olasz nyelvkönyvének (1940), felépítése, koncepciója, módszertana sok ponton mutat hasonlóságot Fest tankönyvével. A szerző, Honti Rezső „neolatin nyelvészettel kezdte pályáját. 1900-ban - 21 éves korában - ebből doktorált, s 1901-ben francia és olasz (s mintegy ráadásul német) nyelvből-irodalomból tanári oklevelet kapott. Utóbb úttörő hispanistáinknak is egyike: spanyol szótárat és nyelvtant, a spanyol irodalomról szakértő tanulmányokat írt.” (Radó, 1979, p.1407) Honti Rezső italianista, szótárszerkesztő, fordító, egyetemi magántanár, nyelvtanár. Sokoldalú, több nyelven publikáló értelmiségi. Pályájának kiemelkedő fordításai olasz nyelvről a jelen kutatóinak számára is megkerülhetetlenek (Machiavelli). Nyelvészeti tanulmányaiban kutatásainak eredményeit közli, amelyek még jelenleg is a téma kutatói számára rendkívül fontosak.

Mint nyelvészeti kérdésekkel foglalkozó tudós kutató így fogalmaz: „Az olasz történeti hangtan már meglehetősen kész eredményeket mutatott fel akkor, a mikor az olasz kiejtés gyakorlati és elméleti törvényei iránt fölébredt az érdeklődés. Egy nemzetnél, még az elocutio művészi formáira annyira kényes francziánál sem volt soha olyan égető kérdés a kiejtés problémája, mint az olaszok közt, mert nem volt egyiknek sem annyira decentralizált culturája, mint az olasznak. Talán az olasz nemzet az egyetlen, a mely arra a gondolatra jutott, hogy hivatalosan állapítson meg egy egységes nemzeti kiejtést, a melyet azután kötelezővé tett mindenütt, a hol más nemzetnél csak nyelvtani és helyesírási megállapodások írhatók elő. így lett az olaszban az egységes orthographia mintájára egy egységes orthoepia is." (Honti, 1912, p.208)

Olasz nyelvészeti kérdések elismert kutatója írja meg tehát olasz nyelvkönyvének bevezetőjében tanácsait, ad egyfajta útmutatót, inkább baráti tanácsokat és támogatást az oktatónak és az olasz nyelvet tanuló diákoknak: „A fejezetek a következő szakaszokra oszlanak: 1. Olvasmány, egyes gyakorlati fogalomkör szókincsének megtanítására, 2. Nyelvtan [ezúttal csaknem kizárólag az olasz ige rendszerének ismertetése], 3. Fordításgyakorlat [magyarból olaszra], 4. Szórakoztató vagy költői olvasmány, 5. A gyakorlati 
szöveg feldolgozása kérdés-feleletekben, 6. Rövid párbeszéd, a mindennapi társalgás nyelvének begyakorlására." (Honti, 1940, p.1)

Javaslatai a gyakorló nyelvtanár javaslatai. Számos forrás bizonyítja, hogy nem csak elméleti szakember, fordító, hanem nagy gyakorlattal bíró nyelvtanár is. 1911-12-es tanévben a Királyi Magyar Tudományegyetem tanrendjében olvashatjuk, hogy mint lektor, a következő című kurzust tartotta: „Bevezetés az olasz nyelvbe (nyelvtan és olvasmány); pénteken. Dr. Honti Rezső lector.” (A Budapesti Királyi Magyar Tudományegyetem Tanrendje, 1911, p.133)

Nyelvkönyvének előszavában nagyon udvariasan így fogalmaz: „A könyv használata előtt a tanuló, illetve a tanfolyam vezetője, szíveskedjék a következőket figyelembe venni: 1. A leckéket kezdő főolvasmányt ajánlatos magyarul leírván (illetve a kulcs szövege alapján) olaszra visszafordítani (szóban vagy írásban). 2. A nyelvtanban felsorolt igék nagyrésze nélkülözhetetlen kiegészítése az olasz szókincsnek, tehát jól meg kell tanulni őket." (Honti, 1940, p.1).

Honti Rezső olasz nyelvkönyvének melléklete egy megoldó kulcs, amelynek segítségével a tanár könnyedén ellenőrizhette tanulói fejlődését. A tankönyvben szereplő összes feladat megoldása szerepel itt. Könyve három nagy egységből áll. Az első a feldolgozandó beszédanyag, amely során a tanuló a hétköznapi élet szókészletét sajátítja el: közlekedés, város, posta, levél, színház, hangverseny, zene, képzőművészetek, hivatások, mesterségek, hadsereg(!), szórakozás, sport. Minden témakör, olvasmány feldolgozását egy nyelvtani összefoglaló segíti magyarul (pl. rendhagyó igék ragozása). Ehhez kapcsolódnak a megoldandó feladatok, gyakorlatok, és egy szószedet. A második nagy egység prózai olvasmányokból áll, de ez is a leckék részét képezi, épp úgy, mint a harmadik rész, amelyben verses olvasmányok vannak. „A költői olvasmányokat figyelmesen át kell tanulmányozni, mert ez jó bevezetés az olasz költői, illetve irodalmi nyelv megismeréséhez. Az adomákat és hírlapi szemelvényeket egy-két figyelmes átolvasás után mondja el a tanuló saját szavaival, nem baj, ha eleinte egészen naív és kezdetleges stílusban." (Honti, 1940, p.1)

Honti nyelvkönyvében az interkulturális kompetencia éppen olyan fontos, mint Fest tankönyvében. A hétköznapi kommunikációra felkészítő párbeszédek mellett a prózai és verses olvasmányok egyformán hangsúlyosan szerepelnek. Az olasz nyelvet tanuló diák így megismeri az itáliai művészek nagy alakjait (Giotto, Filippo Brunelleschi, Giorgio Vasari), az olasz irodalom kiemelkedő költőit, íróit (Dante, Goldoni, Leopardi, Pirandello, Palazzeschi, D’Annunzio, Carducci). A klebelsbergi koncepciót határozottan képviseli, elkötelezetten hisz az itáliai kultúra megkerülhetetlenségében. Ami pedig magát a nyelv megtanulását, elsajátítását illeti, Honti világosan fogalmaz: „A szótanulás (...) a leckék gerince marad. A nyelvtani fejtegetések során említett igéket legjobb a szófüzetbe az olvasmányhoz és a gyakorlatokhoz megadott szójegyzékkel együtt beírni. A leckéket bevezető olvasmányok szavait jobb csak akkor megtanulni, mikor az olvasmányt a szójegyzék forgatása segítségével a tanuló már megértette, a magyar mondatoknak olaszra való fordításába ellenben csak akkor fogjon bele, ha előzetesen a szójegyzékben foglat szókat (sic!) megtanulta." (Honti, 1940, p.4) Meggyőződésem, hogy e tanulásmódszertani javaslat 2020-ban is megállja helyét. Honti megállapításait erősíti 
meg, e szakmai alapvetéseket követi Rakonczai ajánlása is: „A következő óra elején (...) az olvasmányi' anyagot kérjük számon fordítás, kérdés-felelet, tartalmi összefoglalás, és ha az anyag alkalmas, párbeszéd formájában. Hogy a tanuló beszédkészsége ne csak negatív jellegű legyen, időnként kiállíthatunk egy-egy tanulót, hogy intézzen kérdéseket társaihoz az elvégzett anyagból. A tapasztalat azt mutatja, hogy a kérdésekre kifogástalanul felelő a legnagyobb zavarba jön, ha kérdéseket kell intéznie a többiekhez. (...) Prózai szövegeket könyv nélkül megtanultatni felesleges, rövidebb költeményeket viszont előnyös igy feladni." (Rakonczai, 1942, p.10)

Nem véletlen tehát, hogy nem csak az interkulturális kompetencia fejlesztése miatt találunk verseket a nyelvkönyvekben, hanem ezek memorizálása, számonkérése a nyelv tanulásának egyik elengedhetetlen eleme. A 12 olvasmányból álló könyv minden egysége tehát a szerző bevezetőben olvasható felépítését követi. „A fejezeteket lezáró párbeszédekhez nem szükséges szójegyzetet adni. A tanuló szokja meg, hogy ne csak egyes szók (sic!) jelentését, hanem összefüggő szavak, frázisok értelmét találja és tanulja meg. Az olasz szöveg mellé adott fordítás alapján könnyen megtanulhatja minden magyar szó és fordulat olasz megfelelőjét." (Honti, 1940, p.10) Minden olvasmány után van fordítási feladat. Jellemzően 15 magyar mondat olaszra fordítását kéri a szerző. Komoly segítséget nyújt azzal, hogy zárójelben megadja a használandó igeidőt, egy-egy kifejezést, szófordulatot. Az olaszról magyarra fordítandó szövegeknél komoly szószedet támogatja a diákot. A fordítási feladatok elvégzéséhez a következő javaslattal él a szerző: „A magyarolasz fordításgyakorlat főképen az olasz frazeológiába kívánja a tanulót jártassághoz segíteni. A magyar mondatokat a gyakorlottabb tanuló fordítsa szóbelileg is, ami nehezebb, de a nyelvkészséget jobban fejleszti. A lefordításra való mondatokat úgy kellett megfogalmazni, hogy a kevéssé gyakorlott tanulót az olasz szerkezetre rávezesse. ezért gyakran vét a szöveg a magyarosság követelményei ellen.” (Honti, 1940, p.1)

Tóth László nyelvkönyvét 1966-ban adták ki Rómában. Abban a hidegháborús környezetben, amikor Magyarország a szovjet érdekszférához tartozott, akkor, amikor a szocialista országokból Olaszországba utazni rendkívül bonyolult és nehézkes volt. Az enyhülés időszaka is csak 1963 után kezdődött.

„1963. július elején Budapestre látogatott az ENSZ főtitkára: a látogatás jelezte, hogy véget ért a Kádár-rendszer nemzetközi elszigeteltsége. 1964. szeptember 15-én megállapodás született az Apostoli Szent Szék és Magyarország között. Az olasz-magyar kapcsolatok fejlődését mutatja, hogy 1962-től újra utazhattak magyar ösztöndíjasok Olaszországba. 1962 végétől megkezdte munkáját Rómában a Magyar Rádió állandó tudósítója. Megnőtt és kezdett megváltozni a Római Magyar Akadémia szerepe. Megindult a turistafogalom is, 1963-ban több mint 22000 magyar turista utazhatott Olaszországba. A Kádár-rendszer „bojkottjának” végét jelezte az is, hogy 1964-ben az Olasz Köztársaság nagyköveti szintre emelte a Magyarországgal fenntartott diplomáciai kapcsolatát." (Horváth, 1982, p.7)

Nem hagyhatjuk figyelmen kívül tehát azt a tényt, hogy ebben az időszakban Magyarországon olaszul tanulni csak olyan tankönyvből lehetett, amelynek hűen tükröznie kellett ezt a politikai, nemzetközi helyzetet. Sokat elárul a szerző az előszóban, amikor azt olvashatjuk, hogy „tömény népnyelvi anyagot adunk, ami minőségileg 
magasabbrendü (sic!), plasztikusabb, képszerübb, eredetibb, zamatosabb, - az olasz etnikum sajátos egyéniségét revelálja." (Tóth, 1966, p.5) Mindazonáltal Tóth még ahhoz az italianista generációhoz tartozott, akik nyelvészeti, irodalmi kutatásokat végeztek Magyarországon és Olaszországban egyaránt. Jelentősebb publikációi külföldön jelentek meg. (A Janus-arcú jelenkori magyar irodalom. Róma, 1955; Magyar-olasz szólásgyűjtemény kezdőknek. Róma, 1957; Adalékok a XIX. századi olaszországi magyartanítás történetéhez. Róma, 1959; Olasz nyelvkönyv. Róma, 1966; Ithakából Ithakába. Bratislava- Bp., 1975; Emlékszőttes. München, 1976.) 1920-1928 között a Czuczor Gergely Bencés Gimnáziumban tanult, ezután a pécsi Erzsébet Tudományegyetem magyar- olasz szakán diplomázott. Rómában és Paviában tanult, majd 1933-ban a debreceni Magyar Királyi Tisza István Tudományegyetemen szerzett doktori fokozatot. 1934-1935-ben ismét Pécsett találjuk, ahol a pécsi Olasz Intézet tanársegéde. 1935 és 1943 között a Római Magyar Intézet titkára, a római egyetemi magyar tanszékének lektora. Versfordításai közül itt most Ady verseinek fordítását emelem ki, hiszen ez az általa írt tankönyvben is szerepel, mint fordítási feladat. (Ady Endre: Asszonyok a parton, Tóth, 1966, p.71) 1944-1946-ban a debreceni Magyar Királyi Tisza István Tudományegyetemen olasz nyelvet és irodalmat tanított. 1946-ban költözött Olaszországba, ahol a római és a nápolyi egyetemen magyar nyelvet és irodalmat oktatott. „(...) a legnagyobb olaszországi egyetemi magyar intézetté vált nápolyi magyar tanszék Várady Imre és Tóth László tanár urak fáradhatatlan tevékenysége eredményeként a magyar történelem és kultúra, a magyar irodalom olaszországi tanulmányozásának igazi mü-helyeivé váltak, ahol a diákok és kutatók a tanszékvezetőktől csak a magyar történelmi múlt, a magyar irodalom és művészet tiszteletét és szeretetét tanulhatták és ismerhették meg." (Sárközy, 1989, p.136)

Tóth László olasz nyelvkönyvének előszavában a sokoldalú irodalomtörténész, italianista ismerteti módszertanát. „Fokozatos haladással fölépített könyvünk, a következő módszertani lépéseket fogja magában foglalni: először, a nyelvtani szabály közlése, másodszor, képletszerű, példával való illusztrálása, harmadszor, néhány etnikailag jellegzetes közmondásban, vagy bizonyító értékű irodalmi, zsurnalisztikai, anekdótaszerű (sic!) példában való fölismertetése és rögzítése, negyedszer, a nyelvtani szabály tősgyökeres szólásmódokban, italianizmusokban való szemléltetése, amivel egyszersmind zárul is az úgynevezett receptív rész." (Tóth, 1966, p.5)

Tehát minden feldolgozandó lecke ezt a logikát követi. Amiben alapvetően eltér az előző tankönyvektől, az az olvasmányok teljes hiánya. Nem követi elődjei elképzeléseit abban, hogy a nyelvtanulót bevezesse a hétköznapi élet kommunikációjába, megmarad az alaktan, a mondattan, az igeidők egyeztetésének meglehetősen száraz ismertetésénél. Az interkulturális kommunikáció kiemelkedő szerepet kap, különösen a fordítási feladatokban. Ezt Tóth produktív résznek nevezi, amely „ötödik módszertani lépése, megfelelő magyar példaanyagnak, olaszra való fordításával óhajtja a közölt nyelvtani szabályt alkalmaztatni, illetve annak alkalmazását gyakoroltatni." (Tóth, 1966, p.5) Tóth olasz nyelvkönyvében nincsenek dialógusok, nincsenek a hétköznapi élettel kapcsolatos, életszerű szituációk. Helyette van sok szólás-mondás, vers, olaszul, magyarul: Ungarettitől, Ady Endrétől, D’Annunziótól. Dante sorai gyakran szerepelnek a fordítandó 
feladatok között. Illusztrációt nem tartalmaz a könyv, ahogy Fest, Honti könyvében sem találunk rajzokat, grafikákat. Mindenképpen azt kell gondolnunk e tankönyveket tanulmányozva, hogy azok a nyelvtanárok, akik ezeket a tankönyveket használták rendkívül felkészültek voltak, épp úgy, ahogy a szerzők is. Hiszen a szerzők oktatták az egyetemeken, középiskolában a leendő olasztanárokat, ők készítették fel a következő olasztanár nemzedéket a nyelv oktatására. Mivel a tankönyvek szerzői maguk is meghatározó tanáregyéniségek voltak, feltételezhetjük, hogy az egyetemeken tőlük tanuló, tanulmányaikat olvasó generáció alapos tudást kapott a pedagógus pályán való helytálláshoz.

A vizsgált tankönyvek fordítási feladatai a legegyszerűbb mondatok fordításából kiindulva juttatják el a diákot a bonyolultabb, különböző korokból származó regényrészlet, novella, sőt vers fordításáig, összhangban a klebelsbergi oktatáspolitika koncepciójával, azaz: az olasz nyelv tanításával az európai kultúra válik elérhetővé.

Összegezve, Fest Aladár, Honti Rezső és Tóth László tankönyveinek fordítási feladatai, a fordítás, az iskolai tananyag alapvetése volt. Megkerülhetetlen, elhagyhatatlan részét képezte a tananyagnak. A legújabb kutatások szerint, a modern nyelvoktatás és pedagógia alapkompetenciáival is összhangban állnak. Fejlesztik az anyanyelvi kompetenciát, a logikus gondolkodást, segíti az interkulturális kommunikációt, a tantárgyközti kapcsolatokat elmélyítik (Makkos, 2018). Az osztálytermi fordítási feladatok „rehabilitációja” véleményem szerint egyre időszerűbb. A 2005-ben bevezetésre került új érettségi rendszer hűen követi az Európa Tanács kompetenciarendszerét. Az ötödik kompetenciát mérő feladatok teljesen hiányoznak már a nyelvtudást mérő tesztekből, nyelvvizsgákból, érettségi feladatsorokból. Az a tény, hogy a fordítás nem szerepel a vizsgakövetelmények között, azt is jelenti, hogy a középiskolában erre nem fordítanak időt a tanárok. „Előbb-utóbb a nyelvoktatásból teljesen kimaradnak a fordítási feladatok, holott társadalmi hasznosságuk mellett a nyelvtanuló teljes körű épülését, kommunikatív kompetenciájának fejlesztését is szolgálja." (Sárosdyné \& Szabó, 2006, p.20)

A fordítási feladatokkal való osztálytermi „küzdelem” rendkívül hasznos, e tényt az angol nyelv oktatásával foglalkozó kutatók is alátámasztják. Az elemzett olasz tankönyveknek gerincét képezte egykor a fordítás gyakorlása, gyakoroltatása. E tankönyvek szerzői modern világunk követendő példái.

„(...)Az idegen nyelvek oktatásából mára szinte teljesen száműzött anyanyelvnek megvan a szerepe és helye az idegen nyelvi órán. Egyrészről bölcs dolog, ha az idegen nyelvek tanulása során a nyelvtanár épít a diákok anyanyelvi tudására, mivel a kontrasztív nyelvoktatás komoly segítséget nyújthat az idegen nyelvek elsajátításában és általában a nyelvi tudatosság fejlesztésében. Másrészről a posztkommunikatív nyelvoktatás korában még mindig az a tapasztalat, hogy a nyelvtanulók nincsenek tudatos birtokában az idegen nyelvek grammatikai és lexikai rendszerének. Mindezek miatt indokolt megfontolni az ötödik nyelvi készség fejlesztésének beépítését a tantermi gyakorlatba." (Makkos, 2018, pp.19-20.)

2005-ig az olaszul tanuló diákok nagy része fordított órán, mivel tanáraik ezt megkövetelték, gyakoroltatták. Az ötödik nyelvi készség fejlesztése minden órán 
valamilyen formában megtörtént. Valóban megfontolandó, hogy ennek a kompetenciának fejlesztését visszaépítsük a gyakorlatba és rehabilitáljuk a fordítást az osztályteremben.

\section{Irodalomjegyzék}

A Budapesti Királyi Magyar Tudományegyetem $\quad$ Tanrendje. 1911. https://adtplus.arcanum.hu/hu/view/ELTE_EgyetemiTanrendek_1911_1/?query=honti\%20rezs\%C5\%9 1\%20lector\&pg=2\&layout=s. Letöltés dátuma:2020. november 21 .

Antal L. (1979).: Elfelejtett olasz nyelvkönyvek a XVII-XVIII. századból. Filológiai Közlöny, 25 (1-2), 165-173.

Bakti M., Csetényi K., Juhász V., \& Szarvas J. (2018).: Legyen élmény a nyelvtanulás! Élményalapú, informális, idegennyelv-tanítási módszertan.

https://arts.u-szeged.hu/download.php?docID=87064 Letöltés dátuma: 2020.11.19.

Bárdos J. (2000).: Az idegen nyelvek tanításának elméleti alapjai és gyakorlata. Budapest: Nemzeti Tankönyvkiadó. http://mek.oszk.hu/18000/18010/18010.pdf. Letöltés dátuma: 2020.11.19.

F. Dárdai Á. (1999).: Tankönyvelemzési modellek a nemzetközi tankönyvkutatásban. Iskolakultúra, 9 (4), 44-53.

http://www.iskolakultura.hu/index.php/iskolakultura/article/view/19040/18830 Letöltés dátuma: 2020. 11. 22.

Fest A. (1887):: Alcune riflessioni sull'educazione. A Fiumei Magyar Királyi Állami Fógimnázium értesítóje, 1882/83-1910/11.

Fest A. (1891):: Agostino Trefort. A Fiumei Magyar Királyi Állami Fógimnázium értesítője, 1882/831910/11.

Fest A. (1926): La grammatica italiana in base a letture e conversazioni. Budapest: Királyi Magyar Egyetemi Nyomda.

Honti R. (1912-1913):: Az olasz kiejtés kérdéséhez. Nyelvtudomány, 1912-1913. 4. kötet (3) 208.

https://adtplus.arcanum.hu/hu/view/NYELVTUD_04/?query=honti\%20rezs\%C5\%91\%20az\%20olasz\%

20kiejt\%C3\%A9s\%20k\%C3\%A9rd\%C3\%A9s\%C3\%A9hez\&pg=217\&layout=s. Letöltés dátuma: 2020.12.

21.

Horváth J.: Magyarország olasz szemmel (1945-1989). In Limes, 2008 (2), 129-142..

Józsa J. \& Pelles T. (1999).: La situazione dei rapporti italo-ungheresi negli anni del 1920 e 1930. (A magyarolasz kapcsolatok helyzete az 1920-30-as években). In Bér M. (szerk.), Storia della scuola italiana di Budapest - A budapesti olasz iskola története (1935-1947). (85-147). Budapest: AEBES.

$\begin{array}{lllll}\text { Iskolai értesítők, } & \text { Fiume } & \text { 1882-1917 }\end{array}$ https://adtplus.arcanum.hu/hu/collection/ADT_IskolaiErtesitok_Fiume_08829_AllamiGimnazium/.

Letöltés dátuma: 2020.11.22.

Józsa J. \& Pelles T. (2000).: Alfredo (Aladár) Fest (1855 - 1943). Fiume - Rivista di Studi Adriatici (Nuova Serie) 2.20 (7-12), 148-153.

http://web.t-online.hu/pellestamas/Tamas/Fest-it.htm. Letöltés dátuma: 2020. 11. 22.

Kaposi J. (2012): A tankönyv szerepének változásai. Iskolakultúra, 22(12), 56-70.

http://www.iskolakultura.hu/index.php/iskolakultura/article/view/21340/21130 Letöltés dátuma: 2020.11. 22.

Kaposi M. (2012): Machiavelli magyarországi hatástörténetének legfontosabb tanulságai. Valóság, 55. (7), 2-26.

https://adtplus.arcanum.hu/hu/view/Valosag_2012/?query=honti\%20rezs\%C5\%91\&pg=815\&layout=s . Letöltés dátuma: 2020.11.15.

Klebelsberg K. (1927): Gróf Klebelsberg Kuno beszédei, cikkei és törvényjavaslatai 1916-1926. Budapest: Athenaeum.

Klebelsberg K. (1927).: La cooperazione intellettuale tra l'Italia e l'Ungheria. Corvina, 7 (13-14), 25-26. 
Magyar joganyagok - 1924. évi XI. törvénycikk a középiskoláról. Netjogtár. https://net.jogtar.hu/getpdf?docid=92400011.TV\&targetdate=\&printTitle=1924.+\%C3\%A9vi+XI.+t\%C3 \%B6rv\%C3\%A9nycikk\&referer=1000ev. Letöltés dátuma: 2020. november 14.

Makkos A. (2018):: A fordítási feladatok megújítása az idegen nyelvek oktatásában. Modern nyelvoktatás 24. (1.) 19-30.

Radó Gy. (1979):: Honti Rezső. Születésének századik évfordulójára. Nagyvilág, 24 (9) 1407. https://adtplus.arcanum.hu/hu/view/NagyVilag_1979/?query=honti\%20rezs\%C5\%91\%20sz\%C3\%BCle t\%C3\%A9s\%C3\%A9nek\&pg=1460\&layout=s._Letöltés dátuma: 2020. 12. 21.

Rakonczai J. (1942).: A modern nyelvek tanítása a középiskolában. Az erdélyi róm. kat. egyházmegyei tanács vezetése alatt álló csíkszeredai róm. kat. Segítő Mária gimnázium évkönyve az 1941-1942. tanévről. https://epa.oszk.hu/03100/03108/00004/pdf/EPA03108_rom_kath_ertesito_1942_005-014.pdf.

Letöltés dátuma: 2020.11. 22.

Sárközy P. (1989):: Az olaszországi hungarológia két úttörője: Várady Imre és Tóth László http://epa.oszk.hu/02400/02425/00004/pdf/EPA02425_Hungarologiailsmerettar_1990_7_130-139.pdf. Letöltés dátuma: 2020.12. 21.

Sárosdyné Szabó J. (2006.):: A kompetencia alapú nyelvtanítás előnyei és buktatói. THL2. A Magyar nyelv és kultúra tanításának szakfolyóirata. 2016 (1-2), 15-21.

http://real.mtak.hu/74997/1/015-021.pdf. Letöltés dátuma: 2020.12. 21.

Simon Pallós P. (2011):: Fest Aladár fiumei korszaka. Könyv és nevelés, 2011 (4), https://folyoiratok.oh.gov.hu/konyv-es-neveles/fest-aladar-fiumei-korszaka. Letöltés dátuma: 2020. 12.21.

Stelli, G. (2014):: Per una storia di Fiume, Rivista di Studi adriatici, 2014 (29) https://www.academia.edu/13069134/Per_una_storia_di_Fiume. Letöltés dátuma: 2020.11. 22.

Szabó A. (2000):: Az 1924. évi középiskolai reform. Új Pedagógiai Szemle, 50 (7-8). 200-204. http://epa.oszk.hu/00000/00035/00040/2000-07-mk-Szabo-1924.html. Letöltés dátuma: 2020.12.21. 